UDC: $378: 004$

DOI: https://doi.org/10.24195/2414-4665-2017-8-23

\author{
Olena Balalaieva, \\ PhD (Candidate of Pedagogical Sciences), senior lecturer, \\ Department of Ukrainian and Classic Languages,
}

Iryna Vakulyk,

PhD (Candidate of Pedagogical Sciences), associate professor, Department of Ukrainian and Classic Languages, National University of Life and Environmental Sciences of Ukraine, 15, Heroiv Oborony Str., Kyiv, Ukraine

\title{
TECHNIQUE OF USING E-TEXTBOOKS FOR TEACHING LATIN TO STUDENTS OF AGRICULTURAL HIGHER EDUCATIONAL INSTITUTIONS
}

The paper deals with the author's technique of using e-textbooks for teaching some aspects of the Latin languagepronunciation, speaking, reading texts, studying the bases of terminology, vocabulary, grammar, etc. to the students of agricultural higher educational institutions. The practical significance of the e-textbook has been proved by the manyyears' experience of implementing the developed technique for experimental and control groups of students studying at agricultural higher educational institutions. By its means the studying of a classic language (at its phonetic, lexical and morphological levels) is actualized, its structural and logic schemes in terms of studying allied disciplines are being formed.

Keywords: model, e-textbook, projecting, Latin, experiment.

\section{Introduction}

The development of the information society is one of the strategic directions of the modern state policy defined by the Law of Ukraine "On the National Informatization Program", "On Prioritized Directions of Innovative Activity in Ukraine", etc. In the National Strategy of the Development of Ukraine for the period up to 2021, it is emphasized that one of the prospects of its development is implementation of information and communication technologies which provides the development and improvement of the educational process, availability and efficiency of education, and the development of the area of modern teaching means (electronic, IC) as one of the main tasks.

Social significance of the issue of implementing ICT into the field of education has caused a great resonance in research studies. Theoretical and methodological foundations of designing and applying the system of e-learning at agrarian universities were considered in the works of $\mathrm{O}$. Hlazunova [10; 13], D. Kasatkin [12], N. Morze [13] and other scientists.

The creation of comfortable conditions of computer support of traditional teaching technologies is a vital need and motivational component of the educational process [7; 8; 19]. The efficiency of teaching any foreign language is affected by multimedia technologies, which visualize theoretical learning material $[4 ; 9 ; 20]$.
The issue of using informational technologies for teaching foreign languages as well as the peculiarities of using computer technologies for teaching Latin were profoundly examined in the works of European researchers: S. Hunt [15], D. Goodhew [14], D. Drozdova [11], L. Landi [16], J. Moss [17], A. Reinhard [18].

Considering the fact that most research studies were conducted through the examples of technical, mathematical or natural disciplines, the designing of e-textbooks for teaching the Latin language to students of agricultural universities is considered quite relevant today.

The paper aims to present the main components of the technique of using an e-textbook for teaching Latin to agricultural university students and analyze the results of experimental testing of its efficiency.

Based on the provisions of systemic, competence, activity, person-centered, and technological approaches, linguistic and methodical principles of teaching classical languages, the principle of complex application of traditional and computer means, teaching methods and forms of the educational process organization, there has been developed a model of using an e-textbook for teaching the Latin language to agricultural university students, which consists of the target, content, technological, and evaluation-resulting units (fig. 1). 


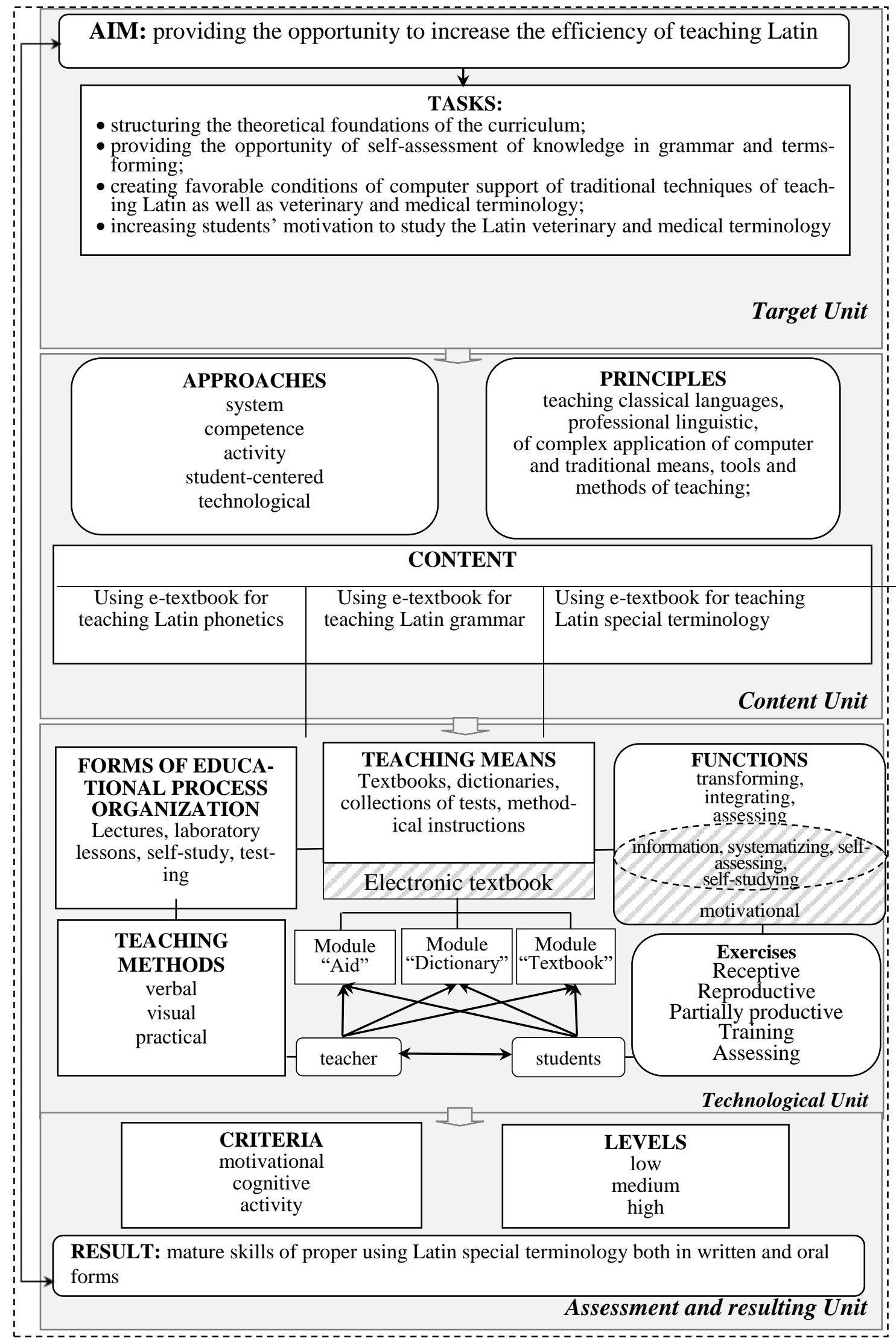

Fig. 1. Model of E-Textbook Application for Teaching Latin to Agricultural University Students 
The presented model is a basis for the development of a technique of using e-textbook for teaching Latin to students of agricultural universities, which involves the following components: aim and tasks, whose realization will contribute to the achievement of the planned results, content, methods and means of teaching, forms of the educational process organization, criteria and levels of assessing the results of studying using the e-textbook. The main goal of using this e-textbook is providing an opportunity to increase the efficiency of teaching Latin on the basis of its didactic potential and our methodical experience in the field of forming skills of using Latin special terminology.

The structural tasks include the structuring of the theoretical foundations of the curriculum, providing the opportunity for self-assessment of knowledge in grammar and terminology, increasing students' interest in studying Latin terminology, creating favorable conditions of computer support of traditional teaching methods.

The technique of using an e-textbook for teaching Latin provides its application when working on the phonetics and grammar, as well as in the process of working with special terminology, which have some differences in terms of the modules.

The developed courseware includes the description of conducting lessons with the application of e-textbook, which has its aim, tasks, content, requirements to the acquired knowledge and skills, examples of exercises for the formation of relevant skills, as well as testing exercises for checking their maturity. The suggested technique is primarily based on the formation of skills of translating Latin terms, though it also deals with orthoepical, orthographical and grammatical skills. Due to the fact some acts (for example, reading, writing and translating) can be consolidated in a form of skills, a student gradually gets rid of the necessity to control and regulate them (controlling the pronunciation, checking the orthography) and is focused on the performance of more complex and important tasks.

The e-textbook can be used for all forms of the educational process organization (lectures, practicals, individual work, testing) and applied as a source of educational information, means for actualization, systematization, self-assessment and correction of knowledge in grammar and foundations of veterinary terminology, as aid in the formation of skills of translating terms.

\section{Research Methods}

In order to check the efficiency of the designed technique of using e-textbook for teaching Latin to agricultural university students we have conducted an experiment.

The research hypothesis implied that the educational process organization on the basis of the suggested model will contribute to the increase of the efficiency of teaching Latin to agricultural university students.

The characteristics of the experiment stages are presented in table 1.

Table 1.

Stages and Methods of the Experiment

\begin{tabular}{|l|l|l|}
\hline \multicolumn{1}{|c|}{ stage } & \multicolumn{1}{|c|}{ content } & \multicolumn{1}{c|}{ methods } \\
\hline summative & $\begin{array}{l}\text { Examining the tendencies and peculiarities of } \\
\text { teaching Latin in agricultural universities, analy- } \\
\text { sis of available e-resources, testing students }\end{array}$ & $\begin{array}{l}\text { analysis, testing, surveying, ques- } \\
\text { tioning }\end{array}$ \\
\hline formative & $\begin{array}{l}\text { Teaching Latin to the respondents using the de- } \\
\text { veloped technique }\end{array}$ & $\begin{array}{l}\text { observation, analysis, testing, ques- } \\
\text { tioning }\end{array}$ \\
\hline generalizing & $\begin{array}{l}\text { Qualitative and quantitative measurement of } \\
\text { empirical data, systematization and generalization } \\
\text { of the research outcomes }\end{array}$ & $\begin{array}{l}\text { analysis, methods of mathematical } \\
\text { statistics, systematization, interpreta- } \\
\text { tion, generalization }\end{array}$ \\
\hline
\end{tabular}

The experiment was held in National University of Life and Environmental Sciences of Ukraine (Kyiv) and Poltava State Agricultural Academy (Poltava) and involved 250 students (who were divided into control $(n=126)$ and experimental $(n=124)$ groups $)$ and 6 teachers.

According to the summative stage results, the number of academic hours allocated for teaching Latin has been significantly decreased. Besides, one can observe the lack of the teaching materials and resources for teaching this language to university students which affects the level of their knowledge and skills.

At the beginning of the experiment students of both groups had equal indices according to all criteria, which is explained by the fact they have never learnt Latin before. This fact provides the homogeneity of the groups.
According to the conditions of the experiment, the students of the control group were taught according to the traditional technique using printed textbooks; and the experimental one was taught according to the suggested model which provided complex use of traditional means and the developed e-textbook "Elementa Linguae Latinae" [4], which was applied at the lab practicals, individual work of students and for testing their knowledge.

Based on modern psycho-pedagogical researches dedicated to the development of the criteria of professional terminological competence maturity, as well as the criteria of the efficiency of the results of teaching we have distinguished motivational, cognitive and activity criteria together with the relevant indices characterizing them in qualitative and quantitative aspects in order to check the efficiency of teaching Latin by means of the developed etextbook (table 2). 
Table 2.

Criteria and Indices of the Efficiency of the Technique of Teaching Latin by Means of the E-Textbook

\begin{tabular}{|l|l|}
\hline Criteria & \multicolumn{1}{|c|}{ Indices } \\
\hline \multirow{2}{*}{ Motivational } & $\begin{array}{l}\text { 1. Focus of educational motivation in the process of studying Latin } \\
\text { 2. Level of inner motivation in the process of studying Latin } \\
\text { 3. Existence of the need for using electronic means for learning Latin }\end{array}$ \\
\hline \multirow{2}{*}{ Cognitive } & $\begin{array}{l}\text { 1. Обсяг знань з нормативного курсу граматики латинської мови } \\
\text { 2. Обсяг знань латинскої ветеринарної термінології }\end{array}$ \\
\hline \multirow{2}{*}{ Activity } & $\begin{array}{l}\text { 1. Maturity of practical, reading, writing, analyzing and translating skills. } \\
\text { 2. The speed of performing tasks on the translation of Latin terms. }\end{array}$ \\
\hline
\end{tabular}

In the process of learning Latin, the students demonstrate varying indices in the motivational, cognitive and activity areas, which is why in order to examine the efficiency of the suggested methodology we have distinguished low, medium and high levels according to every criterion.
The motivational criterion characterizes the focus and level of motivation in the process of studying the discipline, as well as the existence of the need for using electronic means of studying Latin. The interpretation of the distinguished levels is presented in table 3 .

Table 3.

\section{Description of the Levels of Students' Motivation in the Process of Studying Latin}

\begin{tabular}{|c|l|}
\hline Level & \multicolumn{1}{c|}{ Description } \\
\hline low & $\begin{array}{l}\text { External motives of learning Latin prevail. Students understand the objective necessity of studying } \\
\text { this language but consider it as an unavailing tradition, cannot get the purpose and perspective of } \\
\text { studying an extinct language. They are passive at classes, do not take initiative to learn it on their } \\
\text { own as a part of extracurricular activities, do not care if they miss classes, etc. Their interest in the } \\
\text { subject is situational and the stimuli are benefit-focused (they have a desire just to pass an exam } \\
\text { successfully and get scholarship allowance) and organizational (avoiding problems, punishment, } \\
\text { etc.). They do not need to use additional literature and electronic means. }\end{array}$ \\
\hline medium & $\begin{array}{l}\text { Professional motive of studying Latin prevails. Students understand the necessity of studying this } \\
\text { language for their further work, though they are focused on learning only certain practical aspects of } \\
\text { the discipline. They do not use any additional literature, sometimes perform tasks individually but not } \\
\text { because they want it, thus they consider it as a duty. In case of difficulties they refer to electronic } \\
\text { resources. Partially they have external motives of studying (self-affirmation in the student group). } \\
\text { They have systematic interest in studying though they should be guided and controlled by a teacher. }\end{array}$ \\
\hline high & $\begin{array}{l}\text { Cognitive and professional motives of studying Latin prevail. Students undertint the significance of } \\
\text { the language for their future work. They have a desire to acquire new knowledge which is based on } \\
\text { the need for self-development. They tend to study not only practical but theoretical aspects of the } \\
\text { discipline, are initiative at classes. They have stable interest in studying, enjoy the educational pro- } \\
\text { cess, perform all the tasks with pleasure and independently, work with additional literature, use dif- } \\
\text { ferent electronic resources, etc. }\end{array}$ \\
\hline
\end{tabular}

The cognitive criterion makes it possible to examine the level of knowledge in the courseware of Latin and veterinarian terminology, and together with qualitative characteristics of determining the levels, is based on the learning material absorption coefficient $C_{a}$ (according to $\mathrm{V}$. Bespalko), whose value is calculated by means of finding the correlation between the number of correct test answers and the general number of answers in the test. We take the following indicators for determining the level of learning material absorption:

- Low level $\left(C_{a}<0.7\right)$;

- Medium level $\left(0.7 \leq C_{a}<0.85\right)$;

- High level $\left(0.85 \leq C_{a}<1\right)$.
The characteristics of the levels of the efficiency of teaching Latin according to the cognitive criterion are presented in table 4.

The activity criterion makes it possible to examine the level of maturity of reading, writing, analysis and translating skills, as well as the speed of performing tasks on the translation of terms. It is based on the learning material absorption coefficient as well but is measured by means of finding the number of correct actions performed by a student.

The important indicator of this criterion is not only efficiency (result) but also speed of performing practical tasks, namely the translation of veterinarian and medical terms. 
Table 4

Description of the Levels of the Effectiveness of Studying Latin according to the Cognitive Criterion

\begin{tabular}{|c|l|}
\hline level & \multicolumn{1}{c|}{ description } \\
\hline low & $\begin{array}{l}\text { A student reproduces the material referred to phonetics, grammar and word building of the Latin lan- } \\
\text { guage fragmentarily, can give definitions of some terms; knows some models of terms, though he/she } \\
\text { cannot generalize the principles according to which they are formed; knows about } 250-300 \text { basic Latin } \\
\text { anatomic, pharmaceutical and clinical terms, as well as certain affixes and elements of the terms, but } \\
\text { reproduces them with grammatical and orthographic mistakes, knows the rules of execution of the } \\
\text { Latin part of a receipt, though uses them inconsequently. Such students should always be guided by a } \\
\text { lecturer. During testing in certain topics show material absorption coefficient } C_{a}<0.7\end{array}$ \\
\hline medium & $\begin{array}{l}\text { A student demonstrates knowledge and understanding of the main provisions of phonetics, grammar } \\
\text { and word building in the Latin language, provided by the curriculum; knows about 300-400 Latin } \\
\text { anatomical, pharmaceutic and clinical terms and can explain and analyze the models of their building; } \\
\text { knows Latin and Greek affixes and elements of terms; he/she can perform individual tasks though } \\
\text { his/her activities should be corrected by a teacher; during testing according to certain topics the mate- } \\
\text { rial absorption coefficient is } 0.7 \leq K_{a}<0.85\end{array}$ \\
\hline high & $\begin{array}{l}\text { A students possesses systematic, profound knowledge in the course of Latin, can correctly and clearly } \\
\text { reproduce the learnt material both in standard and non-standard situations, understands the bonds be- } \\
\text { tween linguistic phenomena; knows not only 400-500 Latin anatomical, pharmaceutic and clinical } \\
\text { terms but also the principles of constructing the models of terms and their structure, knows the seman- } \\
\text { tics of Latin and Greek affixes and elements of terms, rules of execution of prescriptions; can inde- } \\
\text { pendently gain and use information (including by means of e-tools); has the material absorption coef- } \\
\text { ficient } 0.85 \leq K_{a}<1\end{array}$ \\
\hline
\end{tabular}

According to V. Bespalko [5, p. 70-71], for estimating the content of a textbook and the quality of its mastering by students, apart from the characteristics of the level of absorption and abstraction, the level of automation in the mastering of basic tools and operations, in other words skills, is an extremely important parameter. Along with this, target actions are the correctness of activity, as well as the speed of getting into a gear; administrative acts involve its accuracy, and control ones - its recognition. The automation depends on the speed of performing target actions. The researcher suggests to evaluate the quality of adoption of activity either by means of theoretically established exposition of a trial, or by means of recording time spent using stopwatch study.
The measurement of the speed of performing practical tasks was carried out according to the time necessary for performing a task. The boundary which denotes the time allocated for one lesson (two academic hours) was considered as a low level,

Thus, we distinguish the following levels of assessing the speed of performing a task $\left(\mathrm{V}_{\mathrm{t}}\right)$ :

- $\operatorname{low}\left(\mathrm{V}_{\mathrm{t}} \geq 80 \mathrm{~min}\right.$.);

- medium (60 min. $<\mathrm{V}_{\mathrm{t}}<80$ min.);

- high $\mathrm{V}_{\mathrm{t}}<60 \mathrm{~min}$.

The characteristics of the levels of the efficiency of teaching Latin according to the activity criterion are presented in table 4.5.

Description of the Levels of the Effectiveness of Studying Latin according to the Activity Criterion

\begin{tabular}{|c|l|}
\hline Level & \multicolumn{1}{c|}{ Description } \\
\hline low & $\begin{array}{l}\text { A student can read and write in Latin with a rather great number of orthoepic and orthographic mis- } \\
\text { takes, perform grammatical and word-building analysis of terms using schemas, translate multi- } \\
\text { component terms with the help of a dictionary with a certain number of errors, can execute the Latin } \\
\text { part of the prescription and using a dictionary form complex clinical terms with the assigned meaning; } \\
\text { has the material absorption coefficient } K_{a}<0.7 \text {; rather slowly performs tasks ( } \mathrm{V}_{\mathrm{t}} \geq 80 \text { min.), education- } \\
\text { al actions automation is absent or poor. }\end{array}$ \\
\hline medium & $\begin{array}{l}\text { A student can read and write in Latin with some orthoepic and orthographic mistakes, perform gram- } \\
\text { matical and word-building analysis of terms without any schemas, translate multi-component terms } \\
\text { sometimes using a dictionary, can reveal the essence of the unknown clinical term based on establish- } \\
\text { ing semantics of its elements; has the material absorption coefficient } 0.7 \leq K_{a}<0.85 ; \text { rather quickly } \\
\text { performs tasks }\left(60 \text { min. }<\mathrm{V}_{\mathrm{t}}<80 \text { min.), educational actions are automatized by are unstable. }\right.\end{array}$ \\
\hline high & $\begin{array}{l}\text { A student can fluently read and write in Latin without making mistakes, put and explain the necessity } \\
\text { of stress in the words, make grammatical and word-building analysis of terms, construct multi- } \\
\text { component anatomical terms on the basis of the mastered models, reveal the essence of the unknown } \\
\text { term basing on the knowledge of its elements, make prescriptions in Latin, can interpret the names of } \\
\text { terms into Ukrainian correctly; has the material absorption coefficient } 0.85 \leq K_{a}<1, \text { performs tasks } \\
\text { quickly and properly without any mistakes }\left(\mathrm{V}_{\mathrm{t}}<60 \text { min.), has educational skills which are character- }\right. \\
\text { ized by stability, flexibility and efficiency. }\end{array}$ \\
\hline
\end{tabular}




\section{Research Results}

The comparative analysis of the dynamics of students' motivation has shown that the difference in the increase of the number of the students with inner motives of studying Latin is $10.4 \%$ in favor of the experimental technique.

Besides, we have recorded some positive differences in the learning material mastering in the experimental group which is manifested in the increase of the number of the respondents with medium and high levels of material mastering. In particular, the number of students with the low level of learning material mastering is $14.2 \%$ less in the experimental group as compared to the control one.

In general, according to Student's t-test, the mean score of the experimental group is 0.51 higher than in the control one.

As a result of the carried out experiment it has been found that the speed of performing tests in the experimental group is $7.8 \%$ higher than in the control one (the test validity was confirmed by Pearson's chi-squared test).

The experimental testing has proved the efficiency of teaching Latin according to the developed technique as compared to the traditional methods.

\section{REFERENCES}

1. Balalaieva, O. Yu. (2016). Proektuvannia elektronnykh posibnykiv $\mathrm{z}$ latynskoi movy dlia vyshchykh ahrarnykh navchalnykh zakladiv [Design of Electronic Textbooks in Latin Language for Higher Agricultural Educational Institutions]. Candidate's thesis. Kyiv: NUBiP of Ukraine [in Ukrainian].

2. Balalaieva, O. Yu. (2015). Diahnostyka naiavnosti potreby u vykorystanni elektronnykh zasobiv navchannia latyny studentamy-veterynaramy [Investigation of the existence of needs for using elearning tools for latin language study by studentsveterinarians]. Naukovyi visnyk Natsionalnoho universytetu bioresursiv i pryrodokorystuvannia Ukrainy. Seriia «Pedahohika. Psykholohiia. Filosofiia»-Scientific bulletin of the National University of Life and Environmental Sciences of Ukraine. Series «Pedagogy. Psychology. Philosophy», 208, 1, 8-14 [in Ukrainian].

3. Balalaieva, O. Yu. (2015). Navchannia hramatyky latynskoi movy studentiv-veterynariv za dopomohoiu elektronnoho posibnyka [The methodology of teaching Latin grammar for veterinary students with author's electronic textbook]. Science Rise, 9/1(14), 74-78 [in Ukrainian].

4. Balalaieva, O. Yu. (2014). Elementa Linguae Latinae. Latynsko-ukrainskyi slovnyk veterynarnomedychnykh terminiv : navch.-metod. posibnyk [Elementa Linguae Latinae. Latin-Ukrainian dictionary of veterinary-medical terms: teaching method. manual]. Kyiv: NUBiP of Ukraine [in Ukrainian].

\section{Conclusion}

1. The suggested model of using the e-textbook for teaching Latin to agricultural university students, which is considered as a system of interrelated components unified into target, content, technological, and evaluationresulting parts, can serve as a basis for the development of a relevant technique, whose main components are as follows: aim, tasks, content, methods and means of teaching, forms of the educational process organization, criteria and maturity levels of using the e-tools in the educational process

2. The following general criteria of the effectiveness of the technique of teaching Latin using the e-textbook have been distinguished: motivation, cognitive and activity, together with the correspondent indices characterizing the criteria in qualitative and quantitative aspects.

3. The efficiency of teaching Latin by means of the suggested technique as compared to the traditional methods has been experimentally proved.

The conducted research does not cover all challenges associated with the application of electronic teaching means for teaching Latin, which is why the development of theoretical and methodological bases of using other kinds of e-means for teaching this language are considered to be the prospects of further research studies.

5. Bespalko, V. P. (1988). Teoriia uchebnika : didakticheskii aspekt [Theory of the textbook: the didactic aspect]. Moscow: Pedagogika [in Russian].

6. Vakulik, I. I. (2011). Psikhologicheskie printsipy izucheniya yazyka kak osnova prochnykh znanii [Psychological principles of language learning as the basis of solid knowledge]. Proceedings from Mezhdunarodnaja nauchno-metodicheskaja konferencija "Perspektivy razvitiia vysshei shkoly» - The IV Internacional scientific and methodical conference «Perspectives of the development of the school». (pp. 15-17). Grodno: GGAU [in Russian].

7. Vakulyk, I .I (2017). Pro rol motyvatsii u suchasnomu komunikatyvnomu prostori [About the role of motivation in the private communion room]. Proceedings from '17: Mizhnarodna naukovo-praktychna konferentsiia «Rozvytok suchasnoi osvity: teoriia, praktyka, innovatsii» - The International scientific and practical conference "Development of modern education: theory, practice, innovations». (pp. 63-64). Kyiv: Milenium [in Ukrainian].

8. Vakulyk, I. I. (2016). Rol informatsiinykh tekhnolohii navchannia $\mathrm{u}$ suchasnomu naukovopedahohichnomu prostori [The role of information technology training in modern scientific and pedagogical space]. Proceedings from '16: Mizhnarodna naukovopraktychna konferentsiia "Rozvytok suchasnoi osvity: teoriia, praktyka, innovatsii» - The International scientific and practical conference "Development of modern education: theory, practice, innovations». (pp. 252-253.). Kyiv: Milenium [in Ukrainian]. 
9. Goodhew, D. (2003). Using ICT in Classics. The Teaching of Classics. (pp. 139-145). Cambridge [in English].

10. Hunt, S. (2013). The development of Teaching and Learning through the Use of ICT in the Latin Classroom. Journal of Classics Teaching, 28, 24-28 [in English].

11. Landi, L. (2008). Technology is culture: a new opportunity for teaching and learning Latin. Meeting the Challenge : International Perspectives on the Teaching of Latin. (pp. 121-134). Cambridge : CUP [in English].

12. Moss, J. (2013). Computer-Assisted Learningin Second-Year Latin. Teaching Classical languages : an Online Journal of the Classical Association of the Middle West and South, 4, 2, 85. Retrieved from http:

\section{ЛІТЕРАТУРА}

1. Балалаєва О. Ю. Проектування електронних посібників 3 латинської мови для вищих аграрних навчальних закладів: дис. ... канд. пед. наук: 13.00.10 / О. Ю. Балалаєва. - К., 2016. - 269 с.

2. Балалаєва О. Ю. Діагностика наявності потреби у використанні електронних засобів навчання латини студентами-ветеринарами / О. Ю. Балалаєва // Науковий вісник Національного університету біоресурсів і природокористування України. Серія «Педагогіка. Психологія. Філософія». - К. : Міленіум, 2015. - Вип. 208. - Ч. 1. - С. 8-14.

3. Балалаєва О. Ю. Навчання граматики латинської мови студентів-ветеринарів за допомогою електронного посібника / О. Ю. Балалаєва // Science Rise. - 2015. - T. 9, №1 (14). - C. 74-78.

4. Балалаєва О. Ю.Elementa Linguae Latinae. Латинсько-український словник ветеринарномедичних термінів : навч.-метод. посібник [Електронний ресурс] / О. Ю. Балалаєва. - К. : НУБіП, 2014. - 1 електрон. опт. диск (CD-ROM); 12 см. - Систем. вимоги : Pentium; 32 MbRAM; Windows 98SE/2000/XP/7.

5. Беспалько В. П. Теория учебника : дидактический аспект / В. П. Беспалько. - М. : Педагогика, 1988. $-160 \mathrm{c}$.

6. Вакулик И. И. Психологические принципы изучения языка как основа прочных знаний / И. И. Вакулик // Перспективы развития высшей школы : материалы IV Международной науч.-метод. конф. / редкол. : В.К. Пестис [и др.]. - Гродно : ГГАУ, 2011. - С. $15-17$

7. Вакулик I .I Про роль мотивації у сучасному комунікативному просторі / I .I Вакулик // Розвиток сучасної освіти: теорія, практика, інновації: зб. матеріалів міжнар. наук.-практ. конф., Київ, 23-24 лютого 2017 р. - К. : Міленіум, 2017. - С. 63-64.

8. Вакулик I. І. Роль інформаційних технологій навчання у сучасному науково-педагогічному просторі / I. І. Вакулик // Розвиток сучасної освіти: теорія, практика, інновації: зб. матеріалів міжнар.
tcl.camws.org/sites/default/files/TCL\%20Spring\%202013_0. pdf [in English].

13. Reinhard, A. (2009). Social networking in Latin class: A How-To Guide. Teaching Classical languages : an Online Journal of the Classical Association of the Middle West and South, 1, 1, 4-29. Retrieved from: http://tcl.camws.org/sites/default/files/ TCL_I_i_4-29_Reinhard.pdf [in English].

14. Vakulyk, I. (2016). Factors of linguistic and speech competence formation. Scientific bulletin of the National University of Life and Environmental Sciences of Ukraine. Series «Philology», 248, 52-56 [in English].

15. Vakulyk, I. (2016). Working on terminology and professional vocabulary. Scientific bulletin of the National University of Life and Environmental Sciences of Ukraine. Series «Philology», 245, 303-307 [in English].

наук.-практ. конф., Київ, 23-24 лютого 2016 р. - К. : Міленіум, 2016. - С. 252-253.

9. Goodhew D. Using ICT in Classics / D. Goodhew // The Teaching of Classics, ed. Morwood J. - Cambridge : CUP, 2003. - P. 139-145.

10. Hunt S. The development of Teaching and Learning through the Use of ICT in the Latin Classroom / S. Hunt // Journal of Classics Teaching. - 2013. - №28. - P. 2428.

11. Landi L. Technology is culture: a new opportunity for teaching and learning Latin / L. Landi // Meeting the Challenge : International Perspectives on the Teaching of Latin. Edited by Bob Lister. - Cambridge : CUP, 2008. - P. 121-134.

12. Moss J. Computer-Assisted Learningin Second-Year Latin [Електронний pecypc] / J. Moss // Teaching Classical languages : an Online Journal of the Classical Association of the Middle West and South. - 2013. - Vol. 4, Issue 2. - P. 85. - Availableat : http: // tcl.camws.org/sites/default/files/TCL\%20Spring\%202013_0. pdf.

13. Reinhard A. Social networking in Latin class: A How-To Guide / A. Reinhard // Teaching Classical languages : an Online Journal of the Classical Association of the Middle West and South. - 2009. - Vol. 1, Issue 1. P. 4-29. - Available , at : http://tcl.camws.org/sites/default/files/TCL_I_i_429_Reinhard.pdf.

14. Vakulyk I. Factors of linguistic and speech competence formation / I. Vakulyk // Науковий вісник Національного університету біоресурсів і природокористування України. Серія «Філологічні науки» / Редкол. : С. М. Ніколаєнко, (відп. ред) та ін. - К. : Міленіум, 2016. - Вип. 248. - С. 52-56.

15. Vakulyk I. Working on terminology and professional vocabulary / I. Vakulyk // Науковий вісник Національного університету біоресурсів і природокористування України. Серія «Філологічні науки» / Редкол.: С. М. Ніколаєнко, (відп. ред) та ін. - К. : Міленіум, 2016. - Вип. 245. - С. 303-307. 
Олена Юрї̈на Балалаєва, кандидат педагогічних наук, старший викладач кафедри украӥнськоӥ та класичних мов,

Ірина Іванівна Вакулик, кандидат філологічних наук, дочент кафедри української та класичних мов, Національний університет біоресурсів і природокористування Украӥни, вул. Героїв Оборони, 15, м. Київ, Україна

\section{МЕТОДИКА ВИКОРИСТАННЯ ЕЛЕКТРОННОГО ПОСІБНИКА У НАВЧАННІ ЛАТИНСЬКОЇ МОВИ СТУДЕНТІВ АГРАРНИХ ВНЗ}

Метою дослідження є опис основних компонентів методики використання електронного посібника у навчанні латинської мови студентів аграрних ВНЗ та оприлюднення результатів експериментальної перевірки іiі ефективності. На основі положень системного, компетентнісного, діяльнісного, особистісно-орієнтованого та технологічного підходів, лінгвопрофесійних і методичних принципів навчання класичних мов, принципу комплексного використання традиційних і комп’ютерно зорієнтованих засобів, методів навчання і форм організації освітнього процесу розроблено модель використання електронного посібника у навчанні латинської мови студентів аграрних ВНЗ, що складається з цільового, змістового, технологічного і оцінювально-результативного блоків. Експериментальною базою дослідження слугував Національний університет біоресурсів і природокористування України (м. Київ) та Полтавська державна аграрна академія (м. Полтава). Загалом до участі у проведенні експериментальної роботи було залучено 352 студенти, які продемонстрували неоднорідні показники в мотиваційній, когнітивній і діяльнісній сферах. Відтак для з'ясування ефективності методики навчання латини за допомогою електронного посібника за вказаними критеріями визначено три рівні (низький, середній, високий). Гіпотеза дослідження полягала в тому, що організація процесу навчання на основі методики використання електронного посібника, спроектованого за розробленою моделлю, сприяє підвищенню ефективності навчання латинської мови студентів аграрних ВНЗ. За результатами статистичного аналізу було виявлено, що середній бал в експериментальній групі на 0,51 вище, ніж в контрольній (достовірність підтверджено статистичним аналізом за критерієм Стьюдента). Під час експериментального дослідження 3'ясовано, що в цілому швидкість виконання тестових завдань в експериментальній групі на 7,8\% вища, ніж у контрольній (достовірність підтверджено статистичним аналізом за критерієм $\chi^{2}$ Пірсона). Порівняльний аналіз динаміки спрямованості навчальної мотивації засвідчив, що різниця у прирості кількості студентів, в яких переважають внутрішні мотиви вивчення латини, склала 10,4\% на користь експериментального масиву. Експериментальна перевірка засвідчила перевагу ефективності навчання латини за запропонованою методикою порівняно із традиційною за мотиваційним, когнітивним і діяльнісним критеріями.

Ключові слова: модель, електронний посібник, проектування, латинська мова, експеримент.

Submitted on June, 29, 2017

Reviewed by Doctor of Pedagogy, prof. N. Kostrytsia 